\title{
Impact of Recruitment and Selection Practices on Teaching Faculties Satisfaction at Community Colleges of Nepal
}

\author{
Hari Lal Mainali \\ Ph.D Scholar (Assam Downtown University, Assam India) \\ Email: hari.mainali35@gmail.com \\ Sudhanshu Verma \\ Professor, Assam downtown University, Assam India \\ Email: sudhanshu.verma@adtu.in

\section{Corresponding Author} \\ Hari Lal Mainali \\ DOI: https://doi.org/ 10.3126/irjmmc.v2i4.41550 \\ Received: September 26, 2021; Revised \& Accepted: December 3, 2021; Published: December 22, \\ 2021 \\ C) Copyright: Mainali (2021).
}

\section{ABSTRACT}

The process of attracting, evaluating, and hiring individuals for an organization is known as recruitment. Selection is the process of identifying an individual from a pool of job applicants with the requisite qualifications and competencies to fill jobs in the organization. The purpose of this paper is to explore the effects of recruitment and selection practices on teaching faculty satisfaction in community colleges. The researcher adopted a Qual-Quan approach with a descriptive and cross-sectional research design. A structured questionnaire was applied for quantitative information collection from 49 respondents, and an FGD was conducted to collect qualitative information. Stratified and random sampling techniques were used to select the sample from the targeted population, and data processing was done using SPSS version 26. In order to reach a conclusion, ANOVA, Chi-square and frequency statistical tools were used for data analysis. The analyses showed there was a significant impact of recruitment and selection practices on teaching faculty satisfaction in community colleges of Nepal.

Key words: Recruitment, Selection, Teaching faculties Satisfaction, Community College,

\section{INTRODUCTION}

A community college is a type of educational institution. The term usually refers to a higher educational institution (HEI) that provides quality higher educational workforce. The term can have different meanings in different countries. In Nepalese context, Community colleges are colleges that are funded by the community, have locally generated funds and resources, have a higher level of local participation, and are governed and managed by a college management committee (CMC) (Mandal, 2016). It is also called public college in the reference of Nepal which is difference than USA, UK and Canadian model of community college. Bista \& Gaulee, (2017) connect that community colleges are affiliated with existing central university and all of them offer bachelor and master degree program affiliated and the examination and curriculum are controlled by central university. It has been established by the active participation and contribution of local community and intellectual classes. Physical and 
financial resources are managed by local community. Gaire (2018) suggests that Community colleges are non-profitable educational service delivery organizations.

According to higher education (HE) report (2020) the student's enrollment in community college is 27.41 percent of total enrolment. Around 7592 teaching faculties are currently working under the community colleges across the country. Community college has been playing immense role to promote HE. Government load of HE 33 percent out of 100 percent has been carried by community college. Existence of community college is only rely on its quality of service delivery i.e. satisfaction of its stakeholders (students and community). These colleges as organization comprise of teaching faculties as key HRs who are responsible for implementing educational plans or policies and enhancing educational quality. Organizational effectiveness is highly influenced by the motivation to work and dedication of its faculties to the organization. Faculties should be satisfied and happiness for achieve the targeted vision and mission of the organization. Utilizing cheerful employees at work could be vital issue for organization. More joyful employees tend to be more inventive, execution and profitable, which eventually produces and maintains made strides (Hauret et al., 2020) quality education.

HRs practices should be done by community college as per the rules and regulations of its affiliation university (Gaire, 2018). However, it doesn't see similarities among the community colleges because there is no active monitoring mechanism that makes similarities. University does not take any interest in activities on HR practices of community college. CMC plays immense role in the connection of HR practices which are seen in college wise different that practices directly affect in the motivational and satisfaction aspect of teaching faculties. Though there are several studies on the role of recruitment and selection practices on employee job satisfaction (Cherif, 2020) in different time and place. Nevertheless, it appears no studies on effect of recruitment and selection practices on teaching faculties satisfaction in community colleges of Nepal. Therefore, this research intent to examine the impact of recruitment and selection practices on teaching faculties satisfaction in community colleges of Nepal.

\subsection{Statement of the Problem}

About 12,000 teaching faculties are working under the community colleges affiliated to Tribhuvan University in Nepal. But sadly, community colleges do not have a service commission, which shows that the recruitment and selection practice of teaching faculty is non-existent. Tribhuvan University affiliated community colleges are independent in their HR practices. Concerned universities and the government do not interfere in activities outside the academic side; as such educational institutions have to operate in a self-reliant and autonomous manner. In addition, such campuses manage their own academic staff and teachers and operate according to the campus committee's own rules. So actually, it seems varies in college-wise.

On the basis of literature discussed for the study, what is the status of teacher and staff recruitment and selection practice in community colleges in Nepal? This research has tried to find the answer to the question. Also, the mentioned objectives and hypotheses have been tested. 
This study could further contribute to the literature on the impact of human resource recruitment and selection practices on faculty satisfaction in community colleges in Nepal. There are a large number of community colleges affiliated to Tribhuvan University. This study will contribute to the great practices of recruitment and selection which can result in HR systems and therefore the satisfaction of employee. This will have an affirmative impact on community HE. This study could further contribute to the literature on the impact of human resource recruitment and selection practices on faculty satisfaction in community colleges in Nepal.

\subsection{Objectives}

a. To explore the current teaching faculties' recruitment and selection practices in community college of Nepal.

b. To identify the impact of recruitment and selection practices on teaching faculties' satisfaction in community colleges of Nepal.

\subsection{Research Hypothesis}

H0: Recruitment practices have no impact on the satisfaction of teaching faculty in community colleges.

H0: Selection practices have no impact on the satisfaction of teaching faculty in community colleges.

\section{Delimitations:}

The study covers only community colleges affiliated with Tribhuvan University in Nepal's Bagmati province. Therefore, findings from research in other types of public and private colleges cannot be generalized.

\subsection{Review of the Related Literature}

Higher Education of Nepal: Higher Education (HE) plays a great role in economic and social development in the country. Its preserves and develops historical and cultural property. Similarly, it helps in producing equipped manpower in the world context and it encourages and promotes research in the exceptional areas of education (Upadhaya, 2018). Mandal (2016) explores that there are three types of HEIs under Tribhuvan University (TU) of Nepal which have been mentioned.

Constituent HEI-University itself conducts and regulates the constituent college providing the fund and manages HRs as well physical resources. Such types of colleges are 147 (UGC, 2021).

Community HEI - The College established under community investment, locally generated funds and resources, more participation of local people and governed and managed by CMC is called community HEI, and it is a profitless organization. University and government do not watch closely of its HR practices and such type of organizations run according to its own rules and regulations and are financially autonomous. 538 such type of HEIs (UGC, 2021) are in existences in Nepal.

Private HEI - Fees and other facilities and internal rules of the organization are set by the owner and it is a profitable organization. There are 747such type of HEIs in Nepal(UGC, 2021). 
Out of three types of HEI, constituent HEI runs as per the university rules and regulation across the country where a similarity in its HR practices seems. Community college totally follows the syllabus and evaluation system of the university but doesn't strictly follow the rules of the university in the connection of HRs practices.

Such type of college develops the policies and procedures of HRs itself by taking the references of the connected university. So that naturally, it seems to vary in college wise. And the private college has no formal policy and practices of HRs rather owner's words become rules and regulations. Most of the private colleges are running in the shared system and no formal HR practices. Despite the fact that private colleges have played a significant role in promoting HE in Nepal.

Human Resources Practices: HR practices in an organization promotes employees from exhibiting positive behavior like regularity, punctuality and it keeps employees very far from negative behavior i.e. frustration, irregularities and so on (Sabiu et al., 2019) that generates happiness. In this connection, Hauret et al., (2020) say happier employee tend to be more creative and productive which eventually generates and sustains improved organizational performances. Mira et al., (2019) argue that fair HR practices stimulates to the knowledge, creativity, commitment of employees that help to increase immense performance of organization. In all organizations including educational, HRs are seen some key elements. If these elements became happy and satisfy overall performances of the organization become increase in better than thinking level (Shrouf et al., 2020). Employees may not reach in level of satisfaction form every aspect because it has different dimension although organization should conduct impartial practice, forsaking nepotism and favoritism on HR policies and practices, they may satisfy from the perspectives on policies and practices of the organization. (Alsafadi \& Altahat, 2021) have told that practices of HRs and their implementation are among the most vital element that helps to promoting satisfaction level of the employee. Educational organizations depend largely on the quality and competence of its faculties. Qualified and competent employees can inter into the organization only through the good and bias less practices and they can maximum uplift the height of the organization. Educational organization is very sensitive organization and it has uncountable duties which should complete by faculties and it is impossible by passive employees. Shrouf et al., (2020) say an organization must have dedicated and innovative employees to complete required work. There is a report of its mission telling that employees are most valuable property for each and every organization. To achieve the determined goal organization should have the right person at the right place and right moment (Cherif, 2020). It is possible only after the systematic HR practices of the organization and that creates positive impact on faculties' psychology and it may give satisfaction. Hence, organizations have to pay more attention to their HRs, because implementation of HR practices supports maximizing employees' competences in the organization. There are several internal and external factors that affect day by day in HR practices in the organization. Hence it seems vary from one to another organization and from one place to another (Pania \& Sharma, 2015). In this connection, no study has been conducted on HR practices still in the field of community college and people are really unknown about it. So this study has headed to find out actual condition of HR practices and its relation with 
faculties satisfaction in community colleges in Nepal especially in recruitment and selection domains.

Recruitment Practices: According to the sort of skills, capabilities, characteristics and knowledge that an organization needs, recruitment begins with an established statement of organizational objectives (Anwar \& Shukur, 2015). Recruitment is the finding process of the best or qualified candidate from inside and outside of the organization. Bazana \& Reddy, (2021) express regarding on recruitment, it is a process of an organization that generates a pool of capable candidates applying to an organization for employment. Similarly, favor of above statement (Gopinath, 2016) announces recruitment is a identifying and attracting process of potential candidates from outside and inside of the institution to start evaluating them for forthcoming employment.

Job identification- Job identification and organizational position which incorporates job title, code number of the work, department or division where the duty is found. This part of the verbal description helps to spot and designate the duty. The position's requirements which should relate to the duty must be identified clearly before recruiting begins(Saviour et al., 2016).

Advertisement - Advertisement is a most common image of external sources of recruitment. It should be worded in a manner that rapid response from job seekers and formulate the wording advertisement that is not discriminatory (Saviour et al., 2016).To make advertisement effective and pool of competent candidates, it is announced in national medias of communication like; television, radio, newspaper so on and currently in internet. The advertisement covers areas such as the company, position to be field, recruitment position, qualification, extra skills, registration charge, application closing date, company location including closely postal address (Otoo et al., 2018).

Recruitment process: Only vacancy advertising is often not sufficient to ensure the pool of required number of qualified candidates. The organization should implement the recruitment process in a timely manner, using modern technological solutions, whereby recruitment itself must be guided by a marketing strategy competition in the market requires. Similarly, Bazana \& Reddy, (2021) say that the recruitment processes and practices play the most important role in the organization. (Qazi \& Jeet, 2016) obtained in their study, positive relation among recruitment and selection practices and employee satisfaction.

Selection Practices: An worker choice is a very last selection technique in which any business enterprise attempt to pick out a proper character within side the proper manner to manipulate nicely skilled and certified HRs (Waheed \& Yang, 2019). Odor et al. (2019) emphasis on selection, It is concerned with making final decision by systematic process, to select outstanding applicants from available pool of prospective applicants using standard selection tools. It is the second step of employment process which comes after completion of recruitment. Otoo et al., 2018 argue that identifying suitable and the most appropriate person for particular job come under selection process. (Waheed \& Yang, 2019) explore in their study, without hard and systematic selection process, organization may not be able to catch competent employee which may cause turnover afterwards.(Munyoro et al., 2016) suggest that Structured interviews, psychometric testing, 
skills analysis, competency mapping, bio data, reference checks, background checks, and credit checks are all part of the selection process.

Expert: A subject expert is a person who has an overall understanding of a specific subject. It can be an overall understanding if the process, technology, function, material, outfit, or any other thing involved in the entire selection process (Mansor et al., 2018).

Standard tests: The tests that are carefully constructed by experts have uniformity of procedure in numbering, administering, and interpreting the test results and they are generally made by a professional expert and are understood as standard tests (Adom et al., 2020).Similarly, a standard test is one whose material has been empirically selected and checked, for which norms have been set, standardized means of administering and scoring have been designed, and for which a high degree of objectivity can be scored(Reynolds \& Suzuki, 2012).

Nepotism and favoritism: Sometimes, management of an organization shows the power of their position to influence the selection process by admitting family members, relatives, and friends, and, so on. (Otoo et al., 2018) suggest that it doesn't permit in the recruitment and selection process to achieve its objectives of recruiting candidates by the merits and most qualified candidate for the job. Odor et al. (2019) found in their study the selection practices is very poor. They concluded that the recruitment and selection process and practice is finalized in not based on objective criteria. They concluded high nepotism; favoritism and politics are affected in selection process. Similarly, (Bazana \& Reddy, 2021) found in their study titled on " A critical appraisal of the recruitment and selection process of the Public Protector in South Africa" the result saw negative association between recruitment and selection practices and its association with satisfaction.

\section{MATERIALS AND METHOD USED}

The research adopted a quantitative and qualitative approach with a descriptive crosssectional survey design. Community colleges of Bagmati province were divided into two strata on the basis of QAA certified and Non-certified. Nine Colleges (running master degree program) were selected out of total community colleges, among of them 5 were QAA certified and 4 were Non-certified. Proportionate Stratified and systematic random sampling techniques were used to select the sample from the targeted population. A total of 63 Google form questionnaires were sent by respondents' email. At the end of the information collection period, a total only 49 were validly filled, giving a response rate of $77.77 \%$. So that 49 teaching faculties of community colleges were taken as a sample.

Structured questionnaire was applied for quantitative information collection from 49 respondents, and FGD was conducted to collect qualitative information. Language and feedback translation and expert opinion was done to validity of tool as well as pilot study was conducted among 10 percentages of respondents. Similarly, Cronbach's Alpha test also conducted for reliability test. The reliability shows the values of Cronbach's Alpha for each of the items. The values of alpha were found 0.788 to $0.892(89.2 \%)$. Hence all the 10 variables values were found to be above 0.78 . The result was stretched from the critically discussed by using frequency table, Chi-square test and ANOVA.

\section{RESULT AND DICUSSION}


Table 1: Demographic Information of the Respondents

\begin{tabular}{ccc}
\hline Demographic Variables & Frequency $(\mathrm{N})$ & Percentages $(\%)$ \\
\hline 1. Gender & & \\
Male & 41 & 83.5 \\
Female & 8 & 16.3 \\
\hline Total & 49 & 100 \\
\hline 2. Education level & & \\
Master's & 38 & 77.6 \\
MPhil & 10 & 20.4 \\
PhD. & 1 & 2 \\
\hline Total & 49 & 100
\end{tabular}

Field Survey 2021.

The table-1, summarizes the demographic information of the respondents.

Recruitment Practices of Community Colleges and Faculty Satisfaction:

Table 2: Recruitment Practices of Community Colleges

\begin{tabular}{|c|c|c|c|c|c|c|c|c|}
\hline \multicolumn{8}{|c|}{ Faculty Recruitment Practices of Community Colleges } & \multirow{2}{*}{$\begin{array}{c}\text { Chi- } \\
\text { Square } \\
\text { Value } \\
\text { Sig. (2- } \\
\text { sided) }\end{array}$} \\
\hline \multicolumn{3}{|c|}{ Variables } & Disagre & Neutra & Agre & Strongl & Tota & \\
\hline \multirow{6}{*}{$\begin{array}{l}1 . \quad \text { Colleg } \\
\text { e gives first } \\
\text { priority to } \\
\text { existing HRs } \\
\text { to fill vacant } \\
\text { position }\end{array}$} & & Male & 34.1 & 0 & 41.5 & 24 & & \multirow{2}{*}{$0.099 * *$} \\
\hline & $\mathbf{r}$ & Female & 75 & 0 & 25 & 0 & 100 & \\
\hline & Highes & Master' & 28.6 & 0 & 36.7 & 12.2 & 77.6 & \multirow{3}{*}{$0.139 * *$} \\
\hline & $\mathbf{t}$ & M.phil & 10.2 & 0 & 2 & 8.2 & 20.4 & \\
\hline & Degree & $\mathrm{PhD}$ & 2 & 0 & 0 & 0 & 2 & \\
\hline & \multicolumn{2}{|c|}{ Total } & 40.8 & 0 & 38.8 & 20.4 & 100 & \\
\hline \multirow{6}{*}{$\begin{array}{l}2 . \quad \text { Colleg } \\
\text { e have proper } \\
\text { identification } \\
\text { process of } \\
\text { vacancy need } \\
\text { based (need, } \\
\text { policies and } \\
\text { strategies) }\end{array}$} & Gende & Male & 26.8 & 9.8 & 48.8 & 14.6 & 100 & $0.571 * *$ \\
\hline & $\mathbf{r}$ & Female & 0 & 50 & 50 & 0 & 100 & $*$ \\
\hline & Highes & $\begin{array}{c}\text { Master' } \\
\text { s }\end{array}$ & 16.3 & 16.3 & 36.7 & 8.2 & 77.6 & \multirow{3}{*}{$\begin{array}{c}0.368^{* *} \\
*\end{array}$} \\
\hline & & M.phil & 4.1 & 0 & 12.2 & 4.1 & 20.4 & \\
\hline & & $\mathrm{PhD}$ & 2 & 0 & 0 & 0 & 2 & \\
\hline & \multicolumn{2}{|c|}{ Total } & 22.4 & 16.3 & 49 & 12.2 & 100 & \\
\hline \multirow{6}{*}{$\begin{array}{l}3 . \quad \text { Colleg } \\
\text { e develops a } \\
\text { pool of } \\
\text { potential } \\
\text { qualified } \\
\text { candidates }\end{array}$} & Gende & Male & 24.4 & 12.2 & 51.2 & 12.2 & 100 & \multirow{2}{*}{$0.056 * *$} \\
\hline & $\mathbf{r}$ & Female & 25 & 50 & 12.5 & 12.5 & 100 & \\
\hline & Highes & $\underset{S}{\text { Master' }}$ & 20.4 & 18.4 & 28.6 & 10.2 & 77.6 & \multirow{3}{*}{$0.027 *$} \\
\hline & $\mathbf{t}$ & M.phil & 4.1 & 0 & 16.3 & 0 & 20.4 & \\
\hline & & $\mathrm{PhD}$ & 0 & 0 & 0 & 2 & 2 & \\
\hline & \multicolumn{2}{|c|}{ Total } & 24.5 & 18.4 & 44.9 & 12.2 & 100 & \\
\hline Vacan & Gende & Male & 9.8 & 7.3 & 51.2 & 31.7 & 100 & \multirow{2}{*}{$0.008^{*}$} \\
\hline cy is & $\mathbf{r}$ & Female & 25 & 12.5 & 50 & 12.5 & 100 & \\
\hline
\end{tabular}


International Research Journal of MMC (IRJMMC)

\begin{tabular}{|c|c|c|c|c|c|c|c|c|}
\hline \multirow{4}{*}{$\begin{array}{l}\text { advertised on } \\
\text { college } \\
\text { website and } \\
\text { other medias }\end{array}$} & Highes & $\begin{array}{c}\text { Master' } \\
\mathrm{s}\end{array}$ & 12.2 & 6.1 & 34.7 & 24.5 & 77.6 & \multirow{3}{*}{$0.014 *$} \\
\hline & $\begin{array}{c}t \\
\text { Deoree }\end{array}$ & M.phil & 0 & 0 & 16.3 & 4.1 & 20.4 & \\
\hline & & $\mathrm{PhD}$ & 0 & 2 & 0 & 0 & 2 & \\
\hline & \multicolumn{2}{|c|}{ Total } & 12.2 & 8.2 & 51 & 28.6 & 100 & \\
\hline \multicolumn{3}{|c|}{ Average } & 24.97 & 10.72 & 45.92 & 18.35 & 100 & \\
\hline
\end{tabular}

Source: Researcher Field Survey, 2021

Note: * Significant different among variables $\mathbf{p} \leq \mathbf{0 . 0 5}, * *$ Nearly different among variable $\mathbf{p} \leq \mathbf{0 . 1 0}$ and $* * *$ Highly Similar among variables $\mathbf{p} \geq 10$

Above given table-2, regarding perception of respondents on faculty recruitment practices of community colleges shows that out of the four variables mentioned in the table, overall, 40.8 percent of the respondents were dissatisfied with the statement that "the college gives priority to existing human resources to fill the vacancies" and the dissatisfaction of female teachers were high (75\%). This statement confirms that male and female perception have equality, it means similarity is less (chi-squire $p=0.099$ ). Similarly, according to the respondent's higher education, there is less similar in the statement (chi-squire $p=0.139$ ).

The second variable, "the college has a proper identification process for vacancies based on needs (requirements, policies and strategies)", seems to have a lot of a similar ( $p=0.57$ and 0.36 ) in respondents' perceptions and only 22.4 percent of disagreements. This means that the college recruits new manpower on the basis of need.

There seems to be a significant difference $(p \leq 0.05)$ in the perceptions of the respondents in the fourth and third variables, the percentage of overall disagreement ranges from 12.2 to 22.5 percent, respectively. This means that the colleges have been informing the public through modern media while recruiting new manpower, but they have not taken any initiative for the development of capable and efficient manpower.

Table 3: Satisfaction on Recruitment Practices

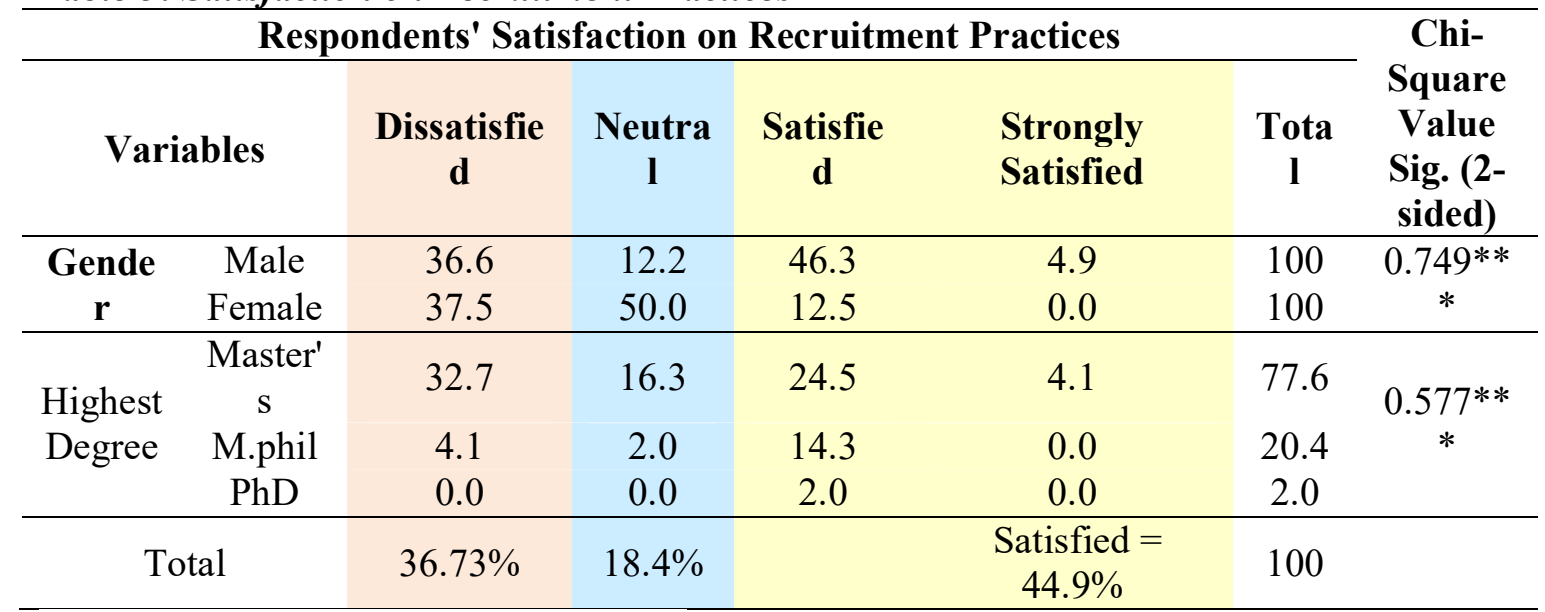

Source: Researcher Field Survey, 2021

Note: *** No Significant different among variables (Highly Similar among variables) $p \geq$ 0.10

Above given table-3, shows that, 44.9 percent of respondents are satisfied, 36.73 percentages are dissatisfied and remaining 18.4 percentages represented neutral no opinion in the recruitment practices of community colleges regarding faculties satisfaction. The result 
also seems to have a lot of a similar $(\mathrm{p}=0.749$ and 0.577$)$ in different respondents' perceptions.

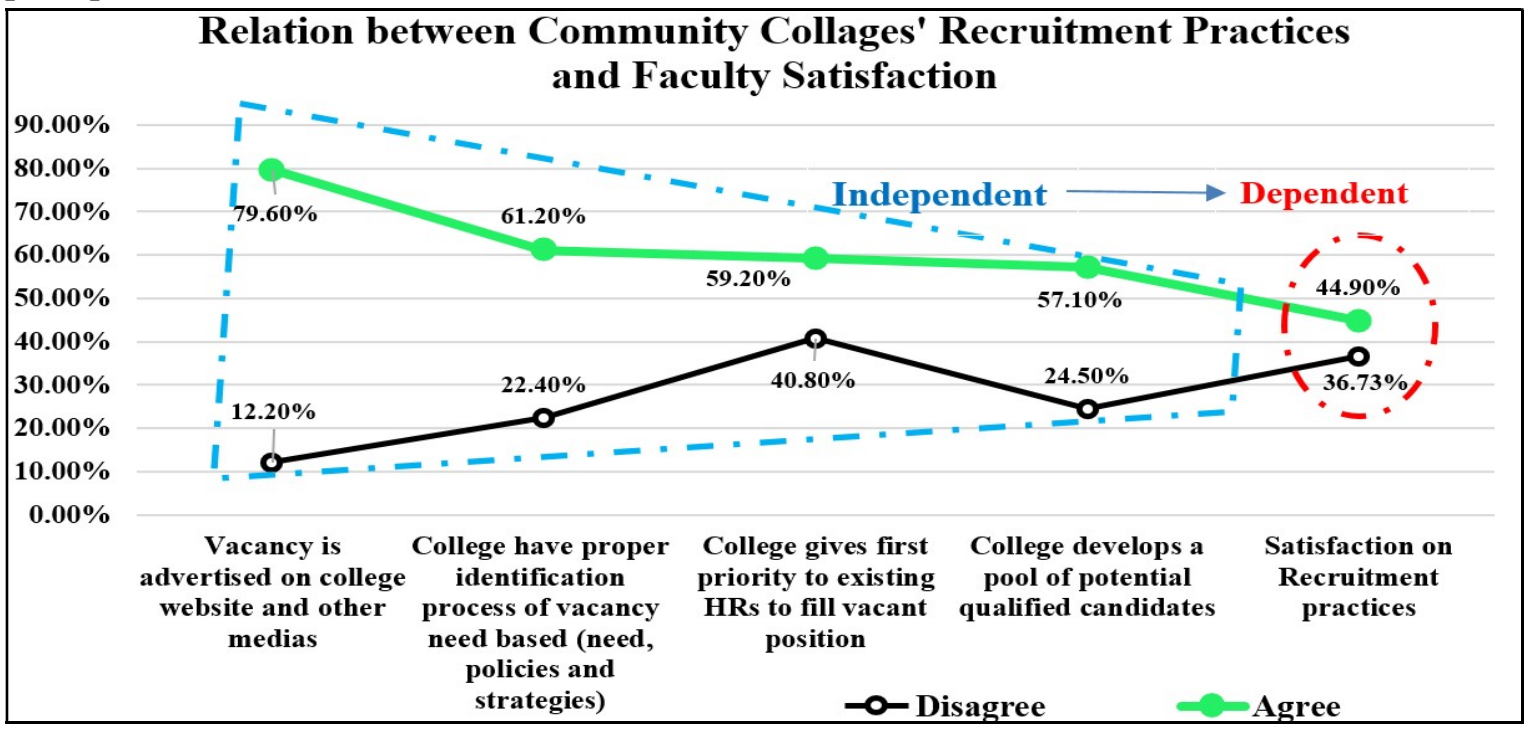

Figure 1: Relation between Community Collages Recruitment Practices and Faculty Satisfaction

Figure 1 above shows the relationship between community college recruitment practice and faculty satisfaction. Of the five variables mentioned in the table, four variables are related to the practices (independent variables) used by the college to fill teaching faculties and one variable is related to faculty satisfaction (dependent variable). The faculties seem to be dissatisfied with the recruitment practice of community colleges and giving priority to the existing manpower to fill the vacancies and advancing the capable manpower. This seems to have reduced overall dissatisfaction. The colleges/the faculties have expressed moderate satisfaction in the practice of informing the public through modern media and evaluating the manpower required for the college while recruiting new manpower.

Hypothesis-1; H0: Recruitment practices have no impact on the satisfaction of teaching faculty in community colleges:

Multi Regressions has used to test the hypothesis to ensure that there is an impact of recruitment practices on teaching faculty satisfaction in community collages of Nepal.

Table 4: Multi-regression R, F and R Square Change Value for Hypothesis Test

\begin{tabular}{|c|c|c|c|c|c|c|c|c|c|}
\hline \multicolumn{10}{|c|}{ Model Summary $^{b}$} \\
\hline \multirow[b]{2}{*}{ Model } & \multirow[b]{2}{*}{$\mathrm{R}$} & \multicolumn{8}{|c|}{ Change Statistics } \\
\hline & & $\begin{array}{l}\text { R } \\
\text { Change }\end{array}$ & Square & $\begin{array}{l}\mathrm{F} \\
\left(\mathrm{ANOVA}^{\mathrm{a}}\right)\end{array}$ & Change & df1 & df2 & $\begin{array}{l}\text { Sig. } \\
\text { Change }\end{array}$ & $\mathrm{F}$ \\
\hline 1 & $.617^{\mathrm{a}}$ & .381 & & 6.761 & & 4 & 44 & 0.000 & \\
\hline
\end{tabular}

a. Predictors: (Constant), Vacancy is advertised on college website and other medias, College develops a pool of potential qualified candidates, College gives first priority to existing HRs to fill vacant position, College have proper identification process of vacancy need based (need, policies and strategies)

b. Dependent Variable: Satisfaction on Recruitment practices 
Table-4 indicated that $\mathrm{F}$ calculated value $=6.761$ and Significant value is $(0.000)$ which is less than $(\alpha \leq .05)$. So, according to the model the null hypothesis is rejected which means the validity of multi-regression, so there is an impact of recruitment practices on teaching faculties' satisfaction in community colleges.

Table also indicated that the correlation coefficient was $\mathrm{R}=.617$ (61.7\%), which indicate a moderate relation between independent variables (recruitment practices) and dependent variable (teaching faculty satisfaction), in addition value of Coefficient of Determination $\left(\mathrm{R}^{2}\right)$ is 0.381 which indicate that $(38.1 \%)$ of variance in teaching faculties' satisfaction may be intercepted through recruitment practices while the rest percent $(61.9 \%)$ is due to other variables that are not included in the model.

Selection Practices of Community Colleges and Faculty Satisfaction

Table 5: Selection Practices of Community Colleges

\begin{tabular}{|c|c|c|c|c|c|c|c|c|c|}
\hline \multicolumn{9}{|c|}{ Faculty Selection Practices of Community Colleges } & \multirow{2}{*}{$\begin{array}{l}\text { Chi- } \\
\text { Square } \\
\text { Value } \\
\text { Sig. (2- } \\
\text { sided) }\end{array}$} \\
\hline \multicolumn{3}{|c|}{ Variables } & $\begin{array}{c}\text { Neve } \\
\mathbf{r}\end{array}$ & $\begin{array}{c}\text { Rarel } \\
\mathbf{y}\end{array}$ & $\begin{array}{c}\text { Sometim } \\
\text { es }\end{array}$ & $\underset{n}{\text { Ofte }}$ & $\begin{array}{c}\text { Alwa } \\
\text { ys }\end{array}$ & $\begin{array}{c}\text { Tot } \\
\text { al }\end{array}$ & \\
\hline \multirow{6}{*}{$\begin{array}{l}\text { 1. The } \\
\text { college } \\
\text { uses a } \\
\text { selectio } \\
\text { n } \\
\text { process } \\
\text { based } \\
\text { on } \\
\text { merit } \\
\end{array}$} & \multirow[b]{2}{*}{ Gender } & \multirow{2}{*}{$\begin{array}{l}\text { Male } \\
\text { Femal } \\
\text { e }\end{array}$} & 4.9 & 17.1 & 22 & 14.6 & 41.5 & 100 & \multirow[b]{2}{*}{$0.001^{*}$} \\
\hline & & & 0 & 37.5 & 12.5 & 25 & 25 & 100 & \\
\hline & \multirow{3}{*}{$\begin{array}{l}\text { Highest } \\
\text { Degree of } \\
\text { Responde } \\
\text { nts }\end{array}$} & $\begin{array}{l}\text { Master } \\
\text { 's }\end{array}$ & 4.1 & 18.4 & 16.3 & 4.1 & 34.7 & 77.6 & \multirow{3}{*}{$0.004^{*}$} \\
\hline & & M.phil & 0 & 0 & 4.1 & 12.2 & 4.1 & 20.4 & \\
\hline & & $\mathrm{PhD}$ & 0 & 2 & 0 & 0 & 0 & 2 & \\
\hline & \multicolumn{2}{|l|}{ Total } & 4.1 & 20.4 & 20.4 & 16.3 & 38.8 & 100 & \\
\hline \multirow{6}{*}{$\begin{array}{l}\text { 2. Uses } \\
\text { indepen } \\
\text { dent } \\
\text { experts } \\
\text { for } \\
\text { selectio } \\
\text { n }\end{array}$} & \multirow[b]{2}{*}{ Gender } & Male & 22 & 7.3 & 14.6 & 24.4 & 31.7 & 100 & \multirow[b]{2}{*}{$0.011^{*}$} \\
\hline & & $\begin{array}{c}\text { Femal } \\
\mathrm{e}\end{array}$ & 50 & 0 & 25 & 12.5 & 12.5 & 100 & \\
\hline & \multirow{3}{*}{$\begin{array}{l}\text { Highest } \\
\text { Degree of } \\
\text { Responde } \\
\text { nts }\end{array}$} & $\begin{array}{l}\text { Master } \\
\text { 's }\end{array}$ & 26.5 & 4.1 & 10.2 & 14.3 & 22.4 & 77.6 & \multirow{3}{*}{$0.004 *$} \\
\hline & & M.phil & 0 & 0 & 6.1 & 8.2 & 6.1 & 20.4 & \\
\hline & & $\mathrm{PhD}$ & 0 & 2 & 0 & 0 & 0 & 2 & \\
\hline & \multicolumn{2}{|c|}{ Total } & 26.5 & 6.1 & 16.3 & 22.4 & 28.6 & 100 & \\
\hline \multirow{6}{*}{$\begin{array}{l}\text { 3. The } \\
\text { selectio } \\
\mathbf{n} \\
\text { process } \\
\text { is free } \\
\text { from } \\
\text { nepotis } \\
\text { m and } \\
\text { bias } \\
\end{array}$} & \multirow[b]{2}{*}{ Gender } & Male & 14.6 & 22 & 34.1 & 24.4 & 4.9 & 100 & \multirow{2}{*}{$\begin{array}{c}0.305^{*} \\
* *\end{array}$} \\
\hline & & $\begin{array}{c}\text { Femal } \\
\mathrm{e}\end{array}$ & 25 & 0 & 12.5 & 50 & 12.5 & 100 & \\
\hline & \multirow{3}{*}{$\begin{array}{l}\text { Highest } \\
\text { Degree of } \\
\text { Responde } \\
\text { nts }\end{array}$} & $\begin{array}{c}\text { Master } \\
\text { 's }\end{array}$ & 16.3 & 8.2 & 22.4 & 24.5 & 6.1 & 77.6 & \multirow{3}{*}{$\begin{array}{c}0.136^{*} \\
* *\end{array}$} \\
\hline & & M.phil & 0 & 10.2 & 6.1 & 4.1 & 0 & 20.4 & \\
\hline & & $\mathrm{PhD}$ & 0 & 0 & 2 & 0 & 0 & 2 & \\
\hline & \multicolumn{2}{|l|}{ Total } & 16.3 & 18.4 & 30.6 & 28.6 & 6.1 & 100 & \\
\hline \multirow{2}{*}{$\begin{array}{l}\text { 4. Uses } \\
\text { the } \\
\text { standar }\end{array}$} & \multirow[b]{2}{*}{ Gender } & Male & 2.4 & 41.5 & 24.4 & 14.6 & 17.1 & 100 & \multirow[b]{2}{*}{$0.000^{*}$} \\
\hline & & $\begin{array}{c}\text { Femal } \\
\mathrm{e}\end{array}$ & 0 & 37.5 & 37.5 & 25 & 0 & 100 & \\
\hline
\end{tabular}


International Research Journal of MMC (IRJMMC)

Vol. 2 Issue 4 (December, 2021)

ISSN 2717-4999 (Online)

2717-4980 (Print)

\begin{tabular}{|c|c|c|c|c|c|c|c|c|c|}
\hline \multirow{4}{*}{$\begin{array}{l}\text { d test } \\
\text { for } \\
\text { selectio } \\
\text { n }\end{array}$} & \multirow{3}{*}{$\begin{array}{c}\text { Highest } \\
\text { Degree of } \\
\text { Responde } \\
\text { nts }\end{array}$} & \multirow{3}{*}{$\begin{array}{l}\text { Master } \\
\text { 's } \\
\text { M.phil } \\
\text { PhD }\end{array}$} & 0 & 36.7 & 14.3 & 12.2 & 14.3 & 77.6 & \multirow{2}{*}{$0.000 *$} \\
\hline & & & 0 & 4.1 & 12.2 & 4.1 & 0 & 20.4 & \\
\hline & & & 2 & 0 & 0 & 0 & 0 & 2 & \\
\hline & \multicolumn{2}{|c|}{ Total } & 2 & 40.8 & 26.5 & 16.3 & 14.3 & 100 & \\
\hline & \multicolumn{2}{|l|}{ Average } & $\begin{array}{c}12.2 \\
2\end{array}$ & 21.42 & 23.45 & 20.9 & 21.95 & & \\
\hline
\end{tabular}

Source: Researcher Field Survey, 2021

Note: * Significant different among variables $\mathbf{p} \leq \mathbf{0 . 0 5}$ and *** Highly Similar among variables $p \geq 10$

In Table-5, among the respondents' perceptions in the faculty selection practices of community colleges, the first variable mentioned in the table, "The College uses a selection process based on merit", 44.9 percent of the respondents said never, rarely and occasionally. They were dissatisfied. Similarly, the dissatisfaction of female teachers (50 percent) was higher than others. This statement confirms that all types of respondents' perception have different, it means highly significant different (chi-squire $p \leq 0.05$ ).

The second and fourth variables, "Uses independent experts for selection" and "Uses the standard test for selection" seems to have significant different $(p=0.57$ and 0.36$)$ in respondents' perceptions and only 48.4 and 69.3 percent of disagreements respectively. This means that the colleges' selection practices are weak.

The third variable, "the selection process is free from nepotism and prejudice," appears to have a greater similarity in respondents' perceptions (0.305 and 0.136$)$ and greater dissatisfaction $(65.3 \%)$. In other words, the respondents are unanimous in saying that the campuses give more priority to their relationship while conducting the manpower selection process.

Table 6: Satisfaction on Selection Practices

\begin{tabular}{|c|c|c|c|c|c|c|}
\hline \multicolumn{6}{|c|}{ Satisfaction on Selection Practice } & \multirow{2}{*}{$\begin{array}{c}\text { Chi-Square } \\
\text { Value Sig. (2- } \\
\text { sided) }\end{array}$} \\
\hline \multicolumn{2}{|l|}{ Variables } & Dissatisfied & Neutral & Satisfied & Total & \\
\hline \multirow{2}{*}{ Gender } & Male & 14.6 & 39 & 46.3 & 100 & \multirow{2}{*}{$0.159 * * *$} \\
\hline & Female & 37.5 & 25 & 37.5 & 100 & \\
\hline \multirow{3}{*}{$\begin{array}{l}\text { Highest Degree of } \\
\text { Respondents }\end{array}$} & Master's & 16.3 & 28.6 & 32.7 & 77.6 & \multirow{3}{*}{$0.258 * * *$} \\
\hline & M.phil & 0 & 8.2 & 12.2 & 20.4 & \\
\hline & $\mathrm{PhD}$ & 2 & 0 & 0 & 2 & \\
\hline Total & & 18.4 & 36.7 & 44.9 & 100 & \\
\hline
\end{tabular}

Source: Researcher Field Survey, 2021

Note: *** Highly Similar among variables $p \geq 10$ 


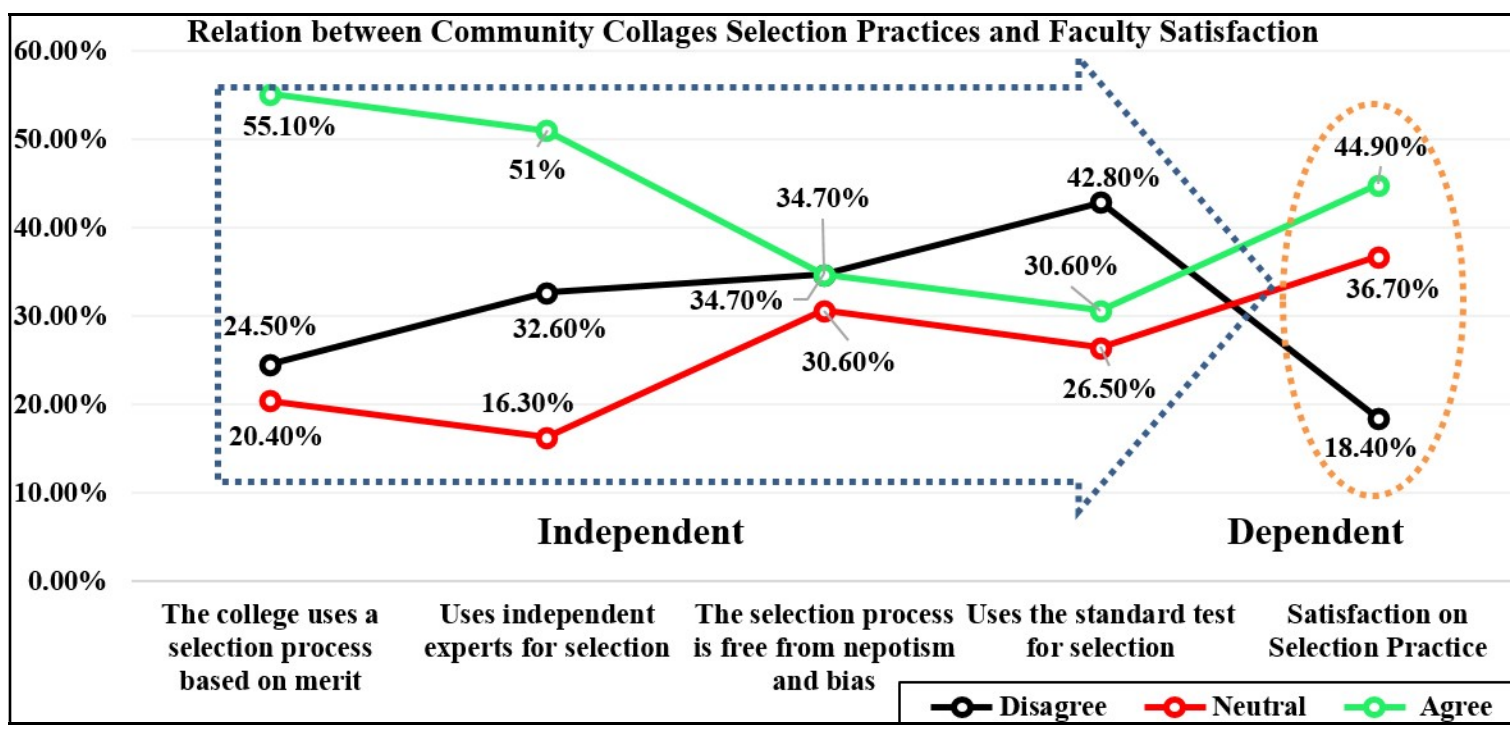

Figure 2: Relation between Community Collages Selection Practices and Faculty Satisfaction

The association between the selection practices of community colleges and the teaching faculties' satisfaction is seen in above figure No.2. The figure demonstrates that there are four selection practices (independent variables) which are used by colleges for teaching faculties' selection, and one is satisfaction (a dependent variable). It is not pleasant to know that the data shows only 44.90 percent of faculties are satisfied with the selection practices, which indicates a below-level of satisfaction. The remaining $36.70 \%$ of faculties did not like to say their opinion about this. It can be assumed that faculties are not fully free to explore the HR practices of their college and that $18.40 \%$ are highly dissatisfied with them.

Hypothesis-2; H0: Selection practices have no impact the satisfaction of teaching faculty in community colleges

Table 7: Multi-regression $R, F$ and $R$ Square Change Value for Hypothesis Test

\begin{tabular}{|c|c|c|c|c|c|c|}
\hline 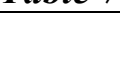 & & & del Summary ${ }^{b}$ & & & \\
\hline & & & Change Statistics & & & \\
\hline Model & $\mathrm{R}$ & R Square Change & F Change (ANOVA ${ }^{\mathrm{a}}$ ) & df1 & df2 & $\begin{array}{l}\text { Sig. F } \\
\text { Change }\end{array}$ \\
\hline 1 & $.709 a$ & 0.503 & 11.123 & 4 & 44 & 0.000 \\
\hline
\end{tabular}

a Predictors: (Constant), Uses the standard test for selection, The selection process is free from nepotism and bias, Uses independent experts for selection, The college uses a selection process based on merit

b Dependent Variable: Satisfaction on Selection Practice

Table-7, indicates that 'ANOVA' calculated value $(F)=11.123$ and the significance value is (0.00), which is not $(a \geq 0.05)$. It can be proved that purposed alternative hypothesis is statically rejected based on calculated information. Similarly, correlation value $-R$ is displaying .709 indicated that high positive correlation between dependent and independent variables. Similarly, co-efficient value of determination ( $R$ square) is 0.503 which represent those 50.3 percentages variances in teaching faculties satisfaction.

\section{Summary of hypothesis}


International Research Journal of MMC (IRJMMC)

\begin{tabular}{|l|l|l|}
\hline SN & Hypothesis & Result \\
\hline 1 & $\begin{array}{l}\text { Recruitment practice has no impact on the satisfaction of teaching faculty in } \\
\text { community colleges }\end{array}$ & Rejected \\
\hline 2 & $\begin{array}{l}\text { Selection practice has no impact on the satisfaction of teaching faculty in } \\
\text { community colleges }\end{array}$ & Rejected \\
\hline
\end{tabular}

\section{Research Question-1;. Are teaching faculties satisfied with the current recruitment} practices of community colleges?

Researcher has organized a virtual Focus Group Discussion (FGD) for collection qualitative information from representative sample;

One of the respondents of community college explored their opinion on recruitment practices: "During the recruitment process, college does not place a higher value on job identification or job analysis. Although there are formal guidelines for recruitment in the college, there are no systematic practices for job creation and description. Despite the fact that a vacancy notice is published in national daily means of communication, do not attempt to create a pool of potential candidates. So we are not fully satisfied with the recruitment practices of the college."

\section{Research Question-2; Are teaching faculties satisfied with the current selection practices of community colleges?}

Researcher has organized a virtual Focus Group Discussion (FGD) for qualitative information;

Respondents of community college explored their opinion on selection practices:

"A subject expert is hired in the selection practice, but he/she is not independent in its practices. Certain levels of nepotism, favoritism, and political interference are present in the selection process, which has a negative effect on choosing capable candidates from a certain list of candidates. Finally, an unqualified candidate is selected for the position, which helps to decrease the quality of education. Therefore, it should be eliminated from selection practices."

There was not found difference vote of the respondents in qualitative and quantitative information.

\section{Findings}

There was an impact of recruitment practices on teaching faculty satisfaction where the calculated $\mathrm{F}$ value $=(6.761)$ and the significance value was $(0.000)$. There was a moderate correlation between recruitment practices and teaching faculty satisfaction where an $\mathrm{R}$ value was seen. .617. There was an association between the impacts of selection practices on teaching faculties' satisfaction where the calculated $F$ value was greater than the significance level $(11.125 \geq 0.05)$. Similarly, a high positive correlation was found among selection practices and teaching faculty satisfaction.

\section{CONCLUSION}

It can ensure that, for better recruitment and selection practices, the community colleges must apply an equality policy for the candidates. Teaching faculties are important pillars of HEIs because they share innovative knowledge and techniques with students, and 
they should be happy with the organizational HR practices. Community colleges have to run according to the system and avoid nepotism, favoritism, and other biases. Colleges will be more satisfied when colleges have satisfied teaching faculties. Hence, it can be confirmed that satisfied faculties can be delivered with innovative teaching methods and that students can also enjoy the classes. From an overall perspective, it will have a positive effect on the organization's image.

\section{REFERENCES}

Abbasi, S. G., Tahir, M. S., Abbas, M., \& Shabbir, M. S. (2020). Examining the relationship between recruitment $\&$ selection practices and business growth: An exploratory study. Journal of Public Affairs. https://doi.org/10.1002/pa.2438

ALSAFADI, Y., \& ALTAHAT, S. (2021). Human Resource Management Practices and Employee Performance: The Role of Job Satisfaction. The Journal of Asian Finance, Economics and Business, 8(1), 519-529. https://doi.org/10.13106/JAFEB.2021.VOL8.NO1.519

Anwar, G., \& Shukur, I. (2015). Internal Journals of Social Sciences and Educational Study, $1(3), 4-13$.

Bista, K., \& Gaulee, U. (2017). Re-envisioning Community Colleges in Nepal: Preparing All Student for Success. In C. W. Finkl \& C. Makowski (Eds.), Encyclopedia of Coastal Science (pp. 1-16). Springer International Publishing. https://doi.org/10.1007/978-3319-38909-7_46-1

Cherif, F. (2020). The role of human resource management practices and employee job satisfaction in predicting organizational commitment in Saudi Arabian banking sector. International Journal of Sociology and Social Policy, 40(7/8), 529-541. https://doi.org/10.1108/IJSSP-10-2019-0216

Elrehail, H., Harazneh, I., Abuhjeeleh, M., Alzghoul, A., Alnajdawi, S., \& Ibrahim, H. M. H. (2020). Employee satisfaction, human resource management practices and competitive advantage. European Journal of Management and Business Economics, 29(2), 125149. https://doi.org/10.1108/EJMBE-01-2019-0001

Faculty of Economics, Segedinski put 9-11, Subotica, Serbia, Slavić, A., Avakumović, J., \& Faculty of Economics, Segedinski put 9-11, Subotica, Serbia. (2018). Job satisfaction of employees in the higher education. Recent Advances in IT, Tourism, Economics, Management and Agriculture, 914-922. https://doi.org/10.31410/itema.2018.914

Hauret, L., Martin, L., Omrani, N., \& Williams, D. R. (2020). How do HRM practices improve employee satisfaction? Economic and Industrial Democracy, 0143831X2096219. https://doi.org/10.1177/0143831X20962199

Javed, S., Javed, R., Ahmed, N., \& Anjum, D. (2019). Human resource management practices and its impact on job satisfaction among employees in higher education sector. International Journal of Marketing \& Human Resource Management, 10(2). https://doi.org/10.34218/IJMHRM.10.2.2019.001

Jawaad, M., Amir, A., Bashir, A., \& Hasan, T. (2019). Human resource practices and organizational commitment: The mediating role of job satisfaction in emerging 
economy. Cogent Business \& Management, 6(1), 1608668. https://doi.org/10.1080/23311975.2019.1608668

Kamran, A., Dawood, J., \& Hilal, S. B. (2015). Analysis of the Recruitment and Selection Process. In J. Xu, S. Nickel, V. C. Machado, \& A. Hajiyev (Eds.), Proceedings of the Ninth International Conference on Management Science and Engineering Management (Vol. 362, pp. 1357-1375). Springer Berlin Heidelberg. https://doi.org/10.1007/978-3-662-47241-5_114

Mandal, R. B. (2016). Public Participation in governance in community college. Academic Voice Multidisciplinary Journal, 6(1), 1.

Mira, M. S., Choong, Y. V., \& Thim, C. K. (2019). The effect of HRM practices and employees' job satisfaction on employee performance. Management Science Letters, 771-786. https://doi.org/10.5267/j.msl.2019.3.011

Odor, H., Martins, E., \& Bakwuye, C. (2019). Recruitment and Selection Practices in Higher Institutions of Learning Nigeria. Internal Journal of Research in Business Study and Management, 6(10), 31-39.

Opele, A. M., Orundeinde, A. M., \& Adegbola, K. O. (2020). An analysis of human resources practices and quality of work life in Dangote pasta Ltd. International Journal of Scientific and Engineering Research, 11(12), 618-637.

Otoo, I. C., Assuming, J., \& Agyei, P. M. (2018). Effectiveness of Recruitment and Selection Practices in Public Sector Higher Education Institutions: Evidence from Ghana. European Scientific Journal, ESJ, 14(13), 199. https://doi.org/10.19044/esj.2018.v14n13p199

Adom, D., Adu-Mensah, J., \& Dake, D. A. (2020). Test, measurement, and evaluation: Understanding and use of the concepts in education. International Journal of Evaluation and Research in Education (IJERE), 9(1), 109 https://doi.org/10.11591/ijere.v9i1.20457

Bazana, S., \& Reddy, T. (2021). A critical appraisal of the recruitment and selection process of the Public Protector in South Africa. SA Journal of Human Resource Management, 19. https://doi.org/10.4102/sajhrm.v19i0.1207

Gopinath, R. (2016). A Study on Recruitment and Selection in Bsnl With Special Reference to Job Satisfaction in Three Different Ssas Using Sem Modeling. INTERNATIONAL JOURNAL OF SCIENTIFIC RESEARCH, 5(7), 71-74.

Mansor, M. F., Abu, N. H., Abashah, A. N., \& Mohd Kassim, M. A. (2018). Cost Reduction and Business Strategy Matters to Human Resource Outsourcing? A Validation by HR Experts from Government Link Companies (GLC's). MATEC Web of Conferences, 150, 05033. https://doi.org/10.1051/matecconf/201815005033

Munyoro, G., Nyandoro, Z., \& Guti, N. (2016). Recruitment and selection of Academic Staff and Students' learning experience in Private Christian universities indeveloping countries: A case study of Zimbabwe Ezekiel Guti University (ZEGU). AFRICA DEVELOPMENT AND RESOURCES RESEARCH INSTITUTE (ADRRI) JOURNAL, 25(8(3)), 14-27. 
Otoo, I. C., Assuming, J., \& Agyei, P. M. (2018). Effectiveness of Recruitment and Selection Practices in Public Sector Higher Education Institutions: Evidence from Ghana. European Scientific Journal, ESJ, 14(13), 199. https://doi.org/10.19044/esj.2018.v14n13p199

Pania, M., \& Sharma, B. (2015). A Comprehensive Review of Factors Influencing HRM Practices in Manufacturing Industries. Journal of Management Engineering and Information Technology (JMEIT), 2(2), 21-29.

Qazi, S., \& Jeet, V. (2016). Impact of Prevailing HRM Practices on Job Satisfaction: A Comparative Study of Public and Private Higher Educational Institutions in India. International Journal of Business and Management, 12(1), 178. https://doi.org/10.5539/ijbm.v12n1p178

Reynolds, C. R., \& Suzuki, L. A. (2012). Bias in Psychological Assessment: An Empirical Review and Recommendations. In I. Weiner (Ed.), Handbook of Psychology, Second Edition (p. hop210004). John Wiley \& Sons, Inc. https://doi.org/10.1002/9781118133880.hop210004

Saviour, A. W., Kofi, A., \& Yao, B. D. (2016). Impact of recruitment and selection practices on Organiztional performance ( A case study at university of Ghana). Global Journal of Management and Business Research:A Administration and Management, 16(11), 27-33.

UGC. (2021). Annual Report 2019/20 [Annual]. University Grant Comission. www.ugcnepal.edu.np

Waheed, A., \& Yang, J. (2019). Effect of Prejudice and References on Employee Selection Process: Empirical Evidence from Pakistan. Global Business Review, 20(6), 13441360. https://doi.org/10.1177/0972150919848904 